\title{
Re-storying the World: Reviving the Language of Life MADRONNA HOLDEN
}

One day in 1975, Henry Cultee, Chehalis elder from Grays Harbor, Washington, told me he wanted to show me something. He beckoned me aboard the boat he kept moored by his fishing shack at Samamanauwish on the Humptulips River. Samamanauwish was also Henry Cultee's traditional name, inherited along with his luck in fishing from his grandfather's brother. It meant 'between two channels'. In explaining the name he shared with the land, Cultee said, 'I'm living right here', as he pointed out the channels of the Humptulips that ran on either side of his cabin.

Eighty-five year old Cultee stood erect as he poled the river to guide us over the riffles for which his people named this river Hum-m-m-m-p-tulips, the name humming along with water running so fast it cleaned itself out in three days after a rain. As Grays Harbor opened before us, modern frame houses and mill stacks dissolved from view. We entered a world composed of water and sky. The wind danced paths of light on the water. This was the wind that lives here, the one that Henry Cultee's mother told him to run against with his arms outstretched, measuring its gaping mouth, so it would be ashamed of itself and calm down. As we moved on into ancient memory, that lone sentinel of a rock hanging over the harbour shrugged off the name of James Rock (for the pioneer) and relived its history as Sme'um - the place where Wildcat stole fire, singeing his tail with the mark he still wears as a result. The urbanized jumble along the Aberdeen River evaporated on the milky mist behind us, giving way to its more lively self: the Wishkah River ('stink water') where Thunderbird dropped a rotting whale carcass. Across the harbour from us was no longer the Cosmopolis named by pioneers, but Khaisálamish, named after the character of the sandbar where the mythic figure Xwane Xwane kept himself from being swept out to sea in the story that related the origin of the Chehalis way of life.

Power lived in this place. It was here that Henry Cultee's mother's father obtained his Indian doctor power that was as famous as it was dangerous. After he found that power, his grandfather took the name of the place where it lived: Khaisálamish. Whites gave him a white name, but he never dropped his Indian one. Thus he was known as Khaisálamish Pete- or as pioneers anglicized it, Cosmopolis Pete. 
Cultee and I slid smoothly down the harbour channel until we came to a dense array of shell mounds exposed by the action of the water on the shore. Cultee laughed as he pointed out these signs of the generations of sweet feasting of his people here. This was what he wanted to show me: how the land kept the story of the lives of his people here.

The land trades stories with us this way. If we know its stories, it keeps our own. The stories Henry Cultee told expressed an ancient reciprocity between humans and the 'the eyes of the world'. In his tradition, it was how the eyes of the land's multiple lives witness our behaviour that determines the length of our own lives among them. Cultee was one of the generous elders from the indigenous Pacific Northwest who showed me something of what we lose with the stories of a living land - and what we might gain by re-storying our world. That is the topic of this paper.

Val Plumwood ('Struggle'; 'Concept') discusses how the traditions of indigenous Australians might serve as a model for honouring earth others in environmental philosophy. Among such peoples there are 'animated, agentic, and intentional views' of nature - and valuable critical perspectives on our own cultures and their worldviews ('Nature' 12). This essay discusses traditions of the indigenous peoples of Washington, Oregon, and California in that light. I have titled this essay 're-storying' and 're-viving' the language of life, since in our tenure of life on earth, humans have been more prone to subjectify the natural world than to objectify it in the habit of modern industrialism. In his meticulous survey of global cultures, nineteenth-century anthropologist Edward Tylor wrote that the life of indigenous peoples was 'inextricably bound in with the ... mental state where man recognizes in every detail of the world the operation of personal life and will' (285). Carolyn Merchant traced the historical shift from the idea of a living earth to inert matter with the coming of the Renaissance and industrialization in Western Europe - and the spread of European colonialism and capitalism in the Americas (Death of Nature; Ecological Revolutions; Radical Ecology). Joanna Hubbs reconstructed the vision that persists in pockets of peasant peoples in Eastern Europe, who see their relationship with the earth as with a living mother, whose double womb gives them out at birth and takes them back at death. Thus they wake each morning to kiss the ground that bore them.

In his critical survey of the idea of animism, Graham Harvey focuses on the 'concern with the 'proper treatment of peoples, not all of whom are human'(xi) - a concern central to indigenous North America. Irving Hallowell's portrayal of the personalized world so persistent among the Ojibwa that 'any concept of impersonal natural forces is totally foreign' (59), is coincident with the worldview of ancient Californians, among whom 'nothing was inanimate. Animals, plants, rocks, trees, trails, mountains, springs, manufactured objects 
and natural objects - indeed, all things - were people, fully alive and intelligent, with complex and interconnected histories' (78). The traditions discussed in this paper likewise link the recognition of agency in earth others with moral obligations toward them - in marked contrast to the objectification of others in modern capitalism Plumwood details.

The habitats of the diverse cultures I will be discussing ranged from rainforest on the ocean coasts and along Puget Sound, the Olympic Peninsula and northern California; to oak savannah in the inland valleys like the vast Willamette Valley, to more arid lands in Central and Eastern Washington and Oregon on the Middle and Upper Columbia River plateaus. These peoples moved into and out of one another's territories to share fishing stations, hunting territories, and gathering and root digging grounds, coming together in trading centres and in mountain berry-collecting camps. At such gatherings, they shared stories and songs and renewed old acquaintances - and many met their future mates. All these people had strong and specific links to place. Eugene Hunn observes that non-Indians who call themselves native after a single generation can scarcely imagine what it is like to live on a land where one hundred generations of their ancestors are buried (Hunn and Selam). Sometimes these peoples transferred their affinity for place to the federal reservations on which they were relocated, but sometimes the land of their ancestors called them back after generations. Takelma elder Agnes Baker Pilgrim returned to live in southwestern Oregon nearly two hundred miles from the Siletz Reservation on which she is federally enrolled - and to which her ancestors were forcibly removed one hundred and fifty years ago. There she has reinstated the annual salmon ceremony on the spot where her ancestors practiced it for perhaps thousands of years. Esther Stutzman, also enrolled at Siletz, now lives in her ancestral Kalapuya territory on the Charlie Applegate claim - at the place where her great great grandfather first invited the Applegates to take up residence alongside them. Though he was enrolled on the Quinault Reservation in spite of his ancestors' refusal to sign a treaty removing them to this place away from their homeland, Henry Cultee did not live there. Instead he returned in season to the place on the Humptulips River whose name he shared with the inheritance of his people - where he was 'rooted to this ground' beside the river into which he dived as a child to share the river's own long life.

The link between human longevity and rootedness in a community of earth others parallels the idea of 'fitting into country' in the indigenous Australian traditions recounted by Deborah Rose. This view, as Rose points out, is in vivid contrast to the competitive notion of 'survival of the fittest' in industrial society. The latter is exemplified in the narrative of Manifest Destiny with which Cultee's ancestors were all too familiar - and which expressed the 'national conviction' that 'Indians were a race doomed to ... extinction and replacement by the 
civilization of the whites' (Slotkin 418). Notably, the idea that the conquest and replacement of indigenous peoples by whites was a matter of natural law served to alleviate the emigrant sense of responsibility for their actions toward these peoples. Cultee's tradition had a very different perception of natural fitness grounded in 10,000 years of sustainable living here. In their view, those judged most fit before the eyes of earth others were those who 'helped one another'. Thus Cultee's people held care for their land and for one another as a primary ethical tenet. Just as he explained the care that must be taken in utilizing the land's resources, he explained that whatever came from the land was to be shared with others. It was bad manners to imply one had control over food by even a asking a visitor, 'Are you hungry?' One just brought out the food. Other ethics included the care for children on the part of all adults and conscious avoidance of actions that might cause dissention. Cultee told moving stories that illustrated his mother's modeling this ethic in the most difficult of situations.

Chehalis stories also illustrated how those who use their power to overcome others could look forward to having the earth 'shrink their life'. In this context, the emigrant view of progress by conquest was not only delusional but selfdefeating. In the 1940's Upper Chehalis elder Silas Heck (a distant cousin of Cultee's) related an ironic portrayal of Washington Territorial Governor Isaac Stevens, in which the latter told the Indians that whites were so crowded in the East that they would soon be eating one another-and so the Indians should give them their land to prevent this. Heck opined that the Indians felt sorry whites were resorting to cannibalism, but he did not entertain the idea of giving up his land as a result (Smith). There is pointed irony here: the society that sees evolutionary fitness in Manifest Destiny's version of 'might makes right' sets itself up for dissension within and without. 'Eating one another' is also an apt metaphor for a people so grasping it seemed they might eat up the whole land. Henry Cultee told me his version of the traditional story in which Bluejay visits the Land of the Dead. In it, Bluejay finds the white man in central residence among the dead, surrounded by numerous Indian tribes and other species he has put there - still declaring 'eat it all up!'

It certainly seemed that emigrants wanted to catch all the fish-or kill them trying. Cultee was horrified at the waste he witnessed when an early salmon cannery dammed up the river to create a salmon trap, causing so many salmon to back up against the dam that the cannery could not handle them, so that they had to hire several scows to tow the rotting fish out to sea to dump them. Charles Wilkinson reports a similar incident on Puget Sound (Crossing). Though they themselves had the technology to 'catch them all', the Indians chose instead to moderate themselves out of respect for the salmon they considered 'kindred spirits capable of engaging in interpersonal relationships'. When whites arrived, these people were harvesting seven times the contemporary 
catch in a sustainable fashion. In his study of salmon runs on the Columbia River beginning in pre-human times, Jim Lichatowich attributes the abundance of Indian fisheries to their partnership ethic, which allowed the Indians and the fish to co-evolve over thousands of years (32-41).

The Sahaptin peoples on the Mid-Columbia applied this partnership ethic to the whole of the natural community in which they were situated: they firmly believed that 'People, animals, plants and other forces of nature ... share ... intelligence and will, and thus have moral rights and obligations as PERSONS [emphasis in original]'. In Sahaptin Waq'ádyšwit, meaning life, infuses everything with the "soul" possessed by people as well as animals, plants, and forces of nature', and because all that is waq'ádyšwit is imbued with 'intelligence, will, and consciousness', this forms the moral basis of the reciprocal partnerships between humans and their land. From the 'laws of creation', the Sahaptins learned reciprocity, cooperation, sharing, and thanksgiving (Hunn and French 388; Hunn and Selam).

Life had a comparable moral force among those who lived on southern Puget Sound: '[W]e believe that all things have life in this world. We honour all things. The dirt, rocks, fresh water, salt water, and all things that have breath are sacred' (Hilbert, Miller and Zahir, iii). At a Muckleshoot cultural committee meeting I sat in on, those present listed the tragic litany of sacred sites ravaged by development. As things appeared very bleak, an elder interjected with quiet resolve: 'I guess we just have to go on the side of life'. Likewise Billy Frank, Jr. from the neighboring Nisqually affirmed his faith in the life (emphasis in text) created by nature when queried about hope in the face of current environmental crises. As long as nature does not give up on the life she has put here, neither should we give up on our work to restore, care for and protect it (Wilkinson, Lessons).

In Frank's words:

I don't believe in magic. I believe in the sun and the stars, the water, the tides, the floods, the owls, the hawks flying, the river running, the wind talking. They're measurements. They tell us how healthy things are. How healthy we are. Because we and they are the same. (Wilkinson, Lessons 101)

Wilkinson observes that Frank's philosophy deserves the same intellectual attention we might give to Locke or Rousseau. But its inevitable conclusion, that we 'think of ourselves not as giants but as equals with the runs and herds and packs and groves whose existence is so fragile because of us ... is not only sophisticated' but 'demanding'. Holding this view with Frank's level of personal commitment would impel us to change radically our society to accommodate 
earth others. As Frank puts it, 'We talk about state sovereignty and tribal sovereignty, but those ant communities under the big fir tree are sovereign too. We've got to find a way to protect their sovereignty'. On the Nisqually River one day, Frank and Wilkinson were encircled by a vast number of harbour seals. Whereas non-indigenous fishermen seek legal permission to shoot the seals because they compete for salmon, Frank's response was very different: 'The seals are part of this. We've got to be sure to put some salmon aside for them' (Wilkinson, Lessons 91-104).

This is in profound contrast with the worldview that objectifies earth others, seeing them only in terms of how they affect humans. In the Willamette Valley near Eugene pioneers declared all-out war on the local rattlesnakes, whom one witness claims they killed by the hundreds. This horrified the local Indians, who stated that the snakes clearly 'saluted' humans with their rattles. It was only those rare snakes who failed to communicate with humans by attacking silently that they in good conscience could themselves attack. That is, they would only hurt a snake that violated this perceived contract between species (Barton).

As agents, earth others participate in contracts with humans on their own terms as well as ours. A Palouse story from the mid-Columbia Plateau honours rattlesnakes as linked to the well being of the salmon on which these people depend. Like other stories from this area, this one 'demonstrated that humans do not have dominion over plants and animals but that they are on equal or lower plane than other life'. Contemporary elder Andrew George tells of the time when humans took too many salmon, and the Salmon People met in council to determine a remedy. They decided to approach Rattlesnake to borrow some of his power. After that, when humans took too much, a salmon bit humans and infected them, using the power the ancestral salmon got from Snake. This story serves as a reminder to humans to adhere to the natural law of balance in taking salmon (Trafzer 22).

Among Esther Stutzman's Kalapuyan ancestors who lived in the Willamette Valley, hunting was an activity with considerable spiritual import. A hunter would participate in a special ceremony for five days before and five days after going on a hunt, singing a song to the deer to honour it and declare his intentions - and it seems, to warn the deer so that he might choose whether to be caught. The hunter sang, 'Run! A man is coming to get you, but if you let us get you, we will treat you right'. If a deer was caught, the people must never 'waste a thing' in using this gift-lest the disrespected deer people never return to Kalapuya territory. The Kalapuya specifically maintained deer habitat to invite the herds to stay near local villages. They never took the biggest and best from herds as do modern 'trophy' hunters. Early emigrants on the Santiam witnessed a traditional circle hunt in which the Kalapuya surrounded a herd 
of deer and then picked out the finest animals to release before they took their own kill (Boag). Stutzman described the special joy in seeing the tail of a deer as it leapt away - for by tradition it would carry away all one's negative feeling with it.

The idea of human dominion over hunted animals was so foreign to the Plateau Salish that their language lacked a way to say 'my elk' - since the use of the possessive contradicted the idea that the animal had its own spirit and thus could not be possessed by humans. The idea of ownership of an animal was first introduced to local peoples by nineteenth century Europeans who branded their cattle. Only in that context did the Salish language adopt an expression for ' $m y$ cow'.

'The earth is alive', Stutzman said in one of her visits to my college classes, 'It has a heart'. Thus treating it with respect can 'bring about balance'. She elaborated, 'Always thank the earth. Thank everything, living and non-living, and sometimes pay the earth ... If you take food or basket materials, say thank you. If you swim in the river, say thank you. Respect everything, living and non-living'. She joked that she even tells the weeds she pulls from her garden, 'You are going to a better place'. The attitude of respect and thanksgiving - and the actions of reciprocity that flow from it, make you a 'better-spirited person. You feel better about yourself inside, and when you feel better about yourself, you treat others in a better way'.

We can understand the import of becoming a 'better-spirited' person by contrasting it with the psychic dislocation from land and people critiqued among the emigrants whom Stutzman's ancestors nicknamed the 'moving people', since 'they would only stay a little, move on, stay a little, move on'. Unlike those who were situated in a community of earth others, those so psychically dislocated would treat no one well. Among the Chehalis this malaise came with a failure to listen to others as one scurried frenetically around (Adamson). Among the Pit River people, such 'wanderers' who ran all over the landscape, 'broke things' and it was best to keep away from those in such a state. Okanagan (Upper Columbia/Canadian) Jeanette Armstrong articulates the moral consequences of the lack of belonging that such persons exhibited: 'Okanagans say that 'heart' is where community and land ... become part of us because they are as essential to our survival as is our own skin'. By contrast, 'people without hearts' exhibit 'collective disharmony and alienation from land'. They are blind to the destructive effects of their actions both on themselves and on others (Callahan 35). To belong to the ground of community and place, by contrast, is to become that 'better-spirited' person who understands how to treat others.

Balance is another key concept brought up in Stutzman's words: humans must take from the land to sustain our lives. But if we take too much - or take without 
making a repayment, we harm all life. Daily we make such decisions as does Stutzman when she pulls her weeds - or as did the Kalapuya in both taking deer and letting them go. Stutzman's words indicate the resonance of people and land that should guide such decisions in an agentic world - in which the earth has a heart like our own, and thus should be treated with reciprocity and respect. As Billy Frank stated in asserting we should measure our health by the health of earth others: 'We and they are the same'. The depth of resonance with earth others in the co-immersion in a community of life with them is expressed by the words of Elsie Pitt (mid-Columbia River): 'Someday the land will be our eyes and skin again' (Stowell 104).

Charles Wilkinson used to think that changes in law would address our current environmental crises, but after working with Billy Frank, he thinks we need a change in worldview that prompts us to engage with the natural world with the kind of emotional depth elicited by Indian ceremonies. Such ceremonies affirm covenants between humans and earth others as they relive ancient stories. When 'Grandma Aggie' Baker Pilgrim officiates at the ceremony to honour the first salmon in the Taklema (southwestern Oregon) territory of her ancestors, she tells the story of the struggle of the salmon women making their way upriver against seemingly insurmountable obstacles for the sake of their children. Sharing this story both creates an emotional resonance between humans and salmonand models the courage and persistence with which we might struggle for the future of the children of both species. Plumwood observes that the hierarchy that places some humans over others and all humans over other natural life is based on 'hyper-separation' between the elements of ranked dualisms such as civilized/savage, mind/body, and human/nature (Plumwood, Feminism). Such stories as Pilgrim's obliterate all such separation.

In the early 1900's linguist Jaime de Angulo recorded his frustration in trying to get a term for 'animals' as opposed to humans in the Pit River language. His consultant, 'Wild Bill', insisted there was no such term in the Pit River language, since there was no such distinction between humans and other natural beings in Pit River culture. When pressed, the only equivalent Wild Bill could give for 'animal' was a term that meant 'world-all-over-living' — a category which included what the white men called animals, what they called humans, and even what they saw as objects. In Wild Bill's words, 'Everything is living, even the rocks, even that bench you are sitting on. Somebody made that bench for a purpose, didn't he? Well, then it's alive, isn't it? Everything is alive' (Callahan 240; emphasis in original).

Wild Bill's attribution of life to the bench made 'for a purpose' recognizes that it is animated by our labor and intent - as well as by our use. This view of the bench as 'living' also brings to our attention its source in the living world, as illustrated by a view of the Karok neighbours of the Pit River peoples: 
When a Karok woman went out to collect pine roots, hazel stems and bear-lily roots for her baskets, she moved in an animate and indeed passionate world. She gathered her basket materials from people. ... By plucking roots and stems she was not harming these people but rather honoring them, transforming them into beautiful baskets that would be displayed during ceremonies ... her relationship with the pine tree, hazel bush, and bear-lily was one of partnership ... after all, she and pine tree were both women, and could thereby understand and help each other very well. (Margolin 79)

In this context, to recognize the 'life' of the bench reminds us what the dualism of modern capitalism encourages us to forget: that the goods we consume inevitability depend on natural life. Wild Bill goes on to make an ironic observation on the psychic toll of such forgetting. Since 'objects' can only be rendered in the Pit River language as 'dead people', Wild Bill opined, 'White people think everything is dead... They don't believe anything is alive'. And as a result of living in a deadened world, whites 'are dead themselves'. Notably, these 'objects' are not dead things - since there is no equivalent for 'thing' in the Pit River language. They are formerly living people, whom objectification has in effect murdered (Callahan 240-241).

The habit of treating natural lives as 'objects' readily extends itself to other humans. A Chehalis story features Raven as a 'boss' who commands a 'fish trap' fashioned of human beings, who shiver as they stand immobilized in the river. But Raven-boss pays no attention to the fact that they might have feelings - or voices with which to express them - he does not hear their cries in his singleminded focus on getting his use out of them. In this story, the exploitation is foiled when the traditional Chehalis culture hero happens on the scene and ordains that this is not the way things will be in the future, since 'These people are human beings' (Boas 15-16).

Specifically countering any objectifying stance, a Chehalis grandmother ${ }^{1}$ told me that 'everything important told around here is always told person to person'. Another grandmother, present in 1926 when Thelma Adamson collected Chehalis traditions from her father, had waited for decades to see the book that Adamson would produce. She was delighted when I gave her copies of stories from Adamson's Folktales of the Coast Salish told by elders she had known. But when she read these, she was disappointed. Traditional storytellers

1 A Chehalis grandmother whom I visited many times one day urged me to publish her words. She also asked that I not use her name. This is related partly to traditional humility in this community, but also to an unfortunate history of the selection of 'white favorites' that caused community dissension. I have given anonymity to all the Upper Chehalis grandmothers with whom I worked in order to protect this woman's anonymity in her small community. 
brought stories to life by inhabiting them, using voice and mime-and their own personalities. One of her favourite things about such stories was how 'each one gets it a little different'.

By contrast, ignoring the voices of others is an essential aspect of objectifying them. In a culture sustained by dialogue, there are a multiplicity of voices as opposed to the monological story (Plumwood, 'Concept'; 'Nature') or 'monotheism of memory' (Hillman, 'Myths of the Family') which modern industrial society tells and hears. Adhering to the perspective in which differences between multiple voices are blurred or unimportant, pioneers and territorial officials designated certain indigenous individuals as representatives of their peoples - subsuming voices of whole communities to white-designated 'chiefs' (e.g. Carey; Stern; Youst). Chehalis elders protested this remembered injustice as they stressed that 'no one speaks for anyone else'.

There is a decided contrast between delight in the diversity of tellings - and the assertion that there is only one right - or representative - version of things. The former opens itself to dialogue, as this elder illustrated in her own interaction with me. If I asked a question indicating I misunderstood something about Chehalis traditions, the elder above did not contradict me. Instead, she might say, 'I never heard of that happening around here'. Thus she left room for the possibility that my words might be true in another context - or even true 'around here' in a way that escaped her knowledge. This consideration for the voices of others - even the voice of a young woman who knew so comparatively little about her culture - is a striking counter to what Hillman terms the 'monotheism of memory'. Dialogue implies incompletion in its openness to the other-in the readiness for something more to happen. This Chehalis grandmother used her quick wit to poke fun at the contrasting attempt to have the last word. After watching a Chehalis elder relate his life story on a film, she quipped: 'He did a real nice job. Only thing is, he didn't give us the ending'. The end of the story, of course, can only be his death. This grandmother's wit had something else to teach about the difference between allocating meaning to the world and pinning it down. In an inappropriately academic frame of mind, I once asked her whether the 'Night People' she had spoken of were confined to particular territories. Her response: 'I think the Night People travel in Ford cars. They like women with hair the colour of yours, especially when the sun shines on it as it's going down!'

In contrast with traditions sustained on dialogue among multiple voices - the 'mono-logic' of modern industrial societies gives us the end of the story before it is begun. In what Plumwood terms the 'logic of colonialism', each word or term assumes a static place within the category the speaker ascribes to it. Take this syllogism: 
John is a man

All men walk on two legs

John walks on two legs.

This version of things has its end in its beginning - for what one can logically conclude rests on the identities of ' $\mathrm{John}^{\prime}$ and ' $\mathrm{man}^{\prime}$ ' remaining as they initially are. If that changes - if John is wounded in war and walks on only one leg, for instance - the logic of the syllogism is subverted. One cannot delight in getting things 'just a little different' here. If one opens the definition of 'man' to question, for instance, as does John Stoltenberg in his Refusing to be a Man, where he argues that there are as many definitions of sexual identity as there are individuals, the logic of the syllogism crumbles. Indeed, if anything here moves across categorical boundaries, redefines itself - or simply surprises us it disrupts the logic of the system. This logic, in short, rests on the assumption of changelessness. And since life is characterized by change, we are back in the land of Wild Bill's 'dead people'.

Here we have emptied John of ground-made him an exemplary case of Plumwood's hyper-separation. We have disengaged him from the vitality of words - as well as from his own flesh. In the impulse to make him exist consistently in all times and places, we have made him exist nowhere in actual time and place. We have, in short, created for him the mental disease of dislocation indigenous peoples see as signed by irresponsibility, the tendency to 'break things' and the inability to hear the voices of others. It is a reason for lament, as James Hillman notes, that the scientific worldview following the Enlightenment 'would reduce language by stripping away all ambiguities, emotional undertones, and historical associations to make each word mean one thing and one thing only' (Hillman, The Myth of Analysis 210). In reducing anything to such a symbol, one short-circuits engagement with it - or on its behalf. One cannot seek justice for this symbol - or levy any moral claim in its favour. We may only seek justice for those with whom we share joy, wonder, sadness or laughter - those with whom we share a story.

In contrast with the logic that lifts both thinkers and their thoughts from the world, the metaphor of stories sets them back into it. Metaphor literally means 'to carry across'; it builds bridges to move us across the divide between one kind of life and another. And so in the story told by Pilgrim, salmon and humans and the rivers they swim in are joined in an interwoven drama. Notably metaphor allows flexibility as mono-logic does not. If I say John runs like a deer, I have not exhausted or confined his identity. He may still walk or fly or swim - or run-like innumerable others. There is no principle of contradiction here. Thus the grandmother who made the ironic quip about the Night People driving Ford Trucks could in another context honour them as the spirit-people they were, 
who empathized with human emotion in a way that made them at once scary (they could predict a death) and bearers of gifts (for those who understood they were truly people and spoke of them with commensurate respect).

Metaphor releases both the thinker and the thought to this vitality of context, expanding identities and meanings as it links us to other lives. Thus it sets us on the earth that has a heart like our own, where the deer carries our feelings and the salmon teaches us to struggle for the future of the children of her species and ours. Like all these earth others, Wildcat has a life of his own, but we may bring him across to us on the bridge of story that weaves his physical distinction (a black striped tail), his wily personality, a technological gift (fire) — with a place on the land. Such stories do not constrain earth others by categorizing them; in fact, they do precisely the opposite by recognizing that in their personhood is a 'sovereignty' that 'deserves to be seen' (Wilkinson, Lessons 91). With such stories humans take their place amidst the sovereignty of salmon and seals, rivers and deer and wind.

If we owe indigenous philosophies, as Wilkinson noted, comparable attention to that which we devote to modern environmental philosophers, we also owe them more. Importantly, we owe them solidarity in their struggle for survival in the face of societies like our own. Indeed our conversation with them only has authenticity in both our personal presence - and the critical perspective we gain in viewing our culture and history through their eyes (Diamond; Plumwood, 'Nature'). Such self-reflection is often asked of us as scholars and writers among indigenous peoples - though it is too often absent - as with those who missed the satire of Coast Salish stories in Washington State because they failed to locate themselves in those stories (Holden). Similarly an anthropologist missed the bald humour of the Ojibwa who made up traditions for him to collect while they waited for him, as an Ojibwa woman told me, to be 'honest with himself' by bringing himself into his fieldwork.

It is time for us to be honest with ourselves. Surely we have seen the world held in a stranglehold of objectification long enough. It is time to invite back historical and spatial context, ambiguity, and emotion - to invite back life itself into our writing. I began with a query about what we might lose if we lose the stories of a living land. We only need look around us to see the answer-our whole precious living world is at stake in the choices we have before us.

In this essay, I have also tried to show something of what we might gain as we reclaim what Linda Hogan calls the 'songs of agreement and safekeeping' that depict the covenant humans once made and might make again with life - in all the connotations of sacredness and responsibility of this utterance among the Northwest's traditional peoples. The eyes of the living world are watching us 
now more than ever, urging us to reclaim stories that 'tell us not only how to keep the world alive' but 'how to put ourselves back together again' (Hogan et al. 14).

To gain this gift, we must counter the stance of objectification with our own subjectivity - and counter the perennial disengagement of our time with our own engagement. Val Plumwood does this as she begins her Environmental Culture with her story of coming upon a dying penguin on the beach, carrying it back to her house, and trying helplessly to revive it. The penguin, as both we and Plumwood learn, is one of a community starving en masse as a result of careless human action. The image of Plumwood with that penguin in her arms resonates with us as we move through her philosophical book about our choices in relating to earth others. In Living Downstream, Sandra Steingraber combines her biological research findings with the wrenching personal experience of growing up in a family situated in the midst of a cancer cluster. Her writing de-objectifies epidemiology as well as medical research and treatment - as in her response to finding a cancer cell sample from a woman's breast identified by a lab tag as MCF-7. She refuses the anonymity of this situation by tracing the name of the donor and relating her personal story.

For both Plumwood and Steingraber, their personal presence is a critical accomplishment that dissolves the distance between the human and the natural-along with the privilege of the writer over her subject matter. Their openness to the agency of the other is apparent as they act in response to the need posed by earth others who are suffering at human hands - as in the case of the dying penguin in Plumwood's arms or the 10,000 victims of cancer she researches that Steingraber reminds us each reflect a human life. Perhaps all engagement begins in this way - with our standing in solidarity with earth others, as in the experience shared with the chimpanzee at Stanford University related by Fran Peavey in Intimate Nature. Watching a breeding encounter between an aggressive male chimp and a beleaguered female, Peavey was feeling sympathy for her when the chimp suddenly yanked her chain out of the hands of the rough male caged with her and walked over to Peavey to take her hand. The chimp then proceeded to lead Peavey to the two other women in the watching crowd, joining hands with one of these so that together they formed a small 'support' circle, as Peavey puts it. She effectively ends her telling of this incident here - for then it is up to the reader to respond to this moment of solidarity that 'reached out across all those years of evolution' (Peavey).

There is no objective response to such a story. We can only respond by engaging it with our own presence and self-reflection. This is the way out of the language littered with Wild Bill's 'dead people'. In the face of such oppressive language, stories and their metaphors can carry us across to something else. Such stories are healing in direct proportion to the ways in which they enliven and link our 
world - in direct opposition to the way in which objectification divides it and dislocates us from our belonging to this world. The metaphors we need for this are those like the shaman's comb used to comb Sedna's hair in the profound Inuit story. In that story, a father maims his daughter, trying to bend her to his will, and though he would as soon have her drown as follow her own course in life, she falls to the bottom of the sea to find her real place - where she becomes the catalyst of the natural fertility that sustains her people. But she will only release that fertility in the form of fish and seals if her descendents comb her hair for her, since she is fingerless as a result of her father's abuse.

We, too, need to tell stories in which we find a way to heal the spirit of our histories, stories that tell us how to dive to the bottom of things, to swim into maimed places to untangle the knots between humans and nature, humans and one another. We need to tell stories that imagine how, once we have gone to those depths, we might swim up again to breathe the air we are made for and to lend ourselves to caring for this world that sustains us.

Madronna Holden has worked with the native peoples of the Pacific Northwest and taught anthropology, philosophy, and folklore at universities in the US and abroad for over thirty years. Also a professional storyteller, she is a regular contributor to Parabola. She currently teaches philosophy and women's studies at Oregon State University and writes online at Our Earth/Ourselves: http://www.holdenma. wordpress.com/.

\section{Works Cited}

Adamson, Thelma. Folktales of the Coast Salish. New York: Kraus Reprint, 1969.

Armstrong, Jeanette. 'I Stand with You against the Disorder.' Yes! 8 November 2005. http://www.futurenet.org/issues/spiritual-uprising/i-stand-with-youagainst-the-disorder/ Accessed 28 September 2009.

Barton, Lois, ed. One Woman's West, Recollections of the Oregon Trail and Settling the Northwest Country by Martha Gay Masterson 1836-1916. Eugene, Oregon: Spencer Butte Press, 1986.

Boag, Peter. Environment and Experience. Berkeley: U of California P, 1992.

Boas, Franz. Chehalis Folklore, ms 1926. Collection of American Indian Linguistics, I, American Philosophical Library.

Callahan, Bob, ed. A Jaime de Angulo Reader. Berkeley: Turtle Island Press, 1979. 
Carey, Charles H. General History of Oregon. Portland: Binfords \& Mort, 1971.

Diamond, Stanley. In Search of the Primitive: A Critique of Civilization. New Brunswick, New Jersey: Transaction, 1974.

Hallowell, Irving. 'Ojibwa Ontology, Behavior and World View.' Primitive Views of the World. Ed. Stanley Diamond. New York: Columbia UP, 1960.

Harvey Graham. Animism: Respecting the Living World. New York: Columbia UP, 2006.

Hilbert, Vi, Jay Miller and Zalmai Zahir. 'Foreword.' Puget Sound Geography: Original Manuscripts from T. T. Waterman. Federal Way, Washington: Lushootseed Press: 2001.

Hillman, James. The Myth of Analysis: Three Essays in Archetypal Psychology. Evanston, Ill: Northwestern UP, 1972.

—. 'The Myths of the Family.' New York: Sound Horizons, 1997 (audio recording).

Hogan, Linda, Deena Metzger and Brenda Peterson, eds. Intimate Nature. New York: Fawcett Columbine, 1998.

Holden, Madronna. "Making all the Crooked Ways Straight": The Satirical Portrait of Whites in Coast Salish Folklore.' Journal of American Folklore 89 (1976): 271-293.

Hubbs, Joanna, Mother Russia. Bloomington: Indiana UP, 1988.

Hunn Eugene S. and David H. French. 'Western Columbia River Sahaptins.' Handbook of North American Indians 12. Ed. Deward Walker. Washington, D.C.: Smithsonian, 1998.

-, with James Selam and Family. Nchi'i-Wána 'The Big River': Mid-Columbian Indians and Their Land. Seattle: U of Washington P, 1990.

Lichatowich, Jim. Salmon without Rivers: A History of the Pacific Salmon Crisis. Washington, D.C.: Island Press, 1999.

Margolin, Malcolm, ed. The Way We Lived. California Indian Reminiscences, Stories and Song. Berkeley: Heyday Books, 1981.

McDonough,William. 'Loving All Species for All Times.' City Club of Cleveland Address (20 April 2001). Audiotape transcription.

Merchant, Carolyn. The Death of Nature. San Francisco: Harper and Row, 1980. 
-. Ecological Revolutions: Nature, Gender and Science in New England. Chapel Hill: U of North Carolina P, 1989.

—. Radical Ecology. New York: Routledge, 1992.

Peavey, Fran. 'The Chimpanzee at Stanford.' Intimate Nature. Ed. Linda Hogan, Deena Metzger and Brenda Peterson. New York: Fawcett Columbine, 1998. 344.

Plumwood, Val. 'The Concept of a Cultural Landscape, Nature, Culture and Agency in the Land.' Ethics and the Environment 11.2 (2006): 111-150.

- Environmental Culture: The Ecological Crisis of Reason. London: Routledge, 2002.

-. Feminism and the Mastery of Nature. London: Routledge, 1993.

--. 'Nature in the Active Voice.' Australian Humanities Review 46 (2009): 113129. http://epress.anu.edu.au/ahr/046/pdf/eh03.pdf Accessed 28 September 2009.

- 'The Struggle for Environmental Philosophy in Australia.' Worldviews: Environment, Culture, Religion 3 (1999): 157-178.

Rose, Deborah. 'Fitting into Country: Ecology and Economics in Indigenous Australia.' Capitalism Nature Socialism 19.3 (2008): 118-122.

Slotkin, Richard. The Fatal Environment: The Myth of the Frontier in the Age of Industrialism, 1800-1890. New York: Athenaeum, 1985.

Smith, Herndon, ed. Centralia: The First Fifty Years. Tumwater, Washington: H. J. Quality Printing, 1975.

Steingraber, Sandra. Living Downstream. Reading, Mass: Perseus Books, 1997.

Stern, Theodore. 'Cayuse, Umatilla, and Walla Walla.' Handbook of North American Indians 12. Ed. Deward Walker. Washington, D.C.: Smithsonian, 1998.

Stoltenberg, John. Refusing to be a Man. New York: Penguin, 1989.

Stowell, Cynthia. Faces of a Reservation. Portland: Oregon Historical Society Press, 1987.

Trafzer, Clifford. Grandmother, Grandfather and Old Wolf. East Lansing, Michigan: Michigan State UP, 1998.

Tylor, Edward. The Origins of Culture. New York: Harper Torchbooks, 1958. 
White, Elizabeth. 'Worlds in Collision: Jesuit Missionaries and Salish Indians on the Columbia Plateau, 1841-1850.' Oregon Historical Quarterly 97 (1996): 26-45.

Wilkinson, Charles. Crossing the Next Meridian, Land, Water and the Future of the West. Washington, D.C: Island Press, 1992.

-. Lessons from Franks Landing. Seattle: U of Washington P, 2000.

Youst, Lionel. She's Tricky Like Coyote. Norman: U of Oklahoma P, 1997. 